\title{
「テラヘルツ波技術の最近の展開」特集号によせて
}

\author{
角屋 豊 \\ 広島大学大学院 先端物質科学研究科 ( T739-8530 広島県東広島市鏡山1-3-1)
}

\section{Preface to Special Issue on Recent Advancement of Terahertz Wave Technology}

\author{
Yutaka KADOYA \\ Graduate School of Advanced Sciences of Matter, Hiroshima University, 1-3-1 Kagamiyama, Higashihiroshima, Hiroshima 739-8530
}

(Received April 21, 2012)

遠赤外光またはサブミリ波と呼ばれていた周波数帯の 電磁波に対し，1995年頃から「テラヘルツ波」という呼称 が使われるともに, この領域の研究開発は急速に拡大 した。 今ではCLEOでも1つのカテゴリーとなり，また 昨秋にはIEEEのTransaction誌が発刊された。国内で関連 した発表が最も多い応用物理学会でも，2000年頃から講 演件数が大幅に増加したため，2005年秋には中分類「非 線形光学」が「テラヘルツ全般・非線形光学」と変更され, テラヘルツ波技術が集中的に討議されている.

このように，近年テラヘルツ波に関する研究は非常に 盛んであり，ほぼ毎年のように新しいトピックスや大き な前進が生まれている。本誌においては第37巻10号でパ ラメトリック光源に関する特集が組まれたが, 既に 3 年 を経過し，また同光源以外でも進展が目覚ましいことか ら, 今回, 最新の状況に関する特集を企画させて頂い た。

テラヘルツ波光源は, パルス系とCW系に大別でき る. パルス系は $100 \mathrm{fs}$ 程度以下のパルス光を種として単 一サイクルかそれに近いテラヘルツ波を発生するもの で，スペクトル幅としては数THzから10 THz以上におよ ぶ広帯域なものとなる。一方 $\mathrm{CW}$ 系では, CW光の非線 形過程によって発生させる光学的手法の他に, 共鳴トン ネルダイオードや量子カスケードレーザーといった半導 体デバイスも重要である. 励起用 $\mathrm{CW}$ 光源やデバイスの 事情により, 完全なCW波ではなく $\mathrm{ns}$ 程度のパルス光源 となる場合もあるが，いずれにしても狭帯域であり，分 光などに用いる場合には波長可変性が必要となる.

一般にテラヘルツ領域では, 可視領域と比べて検出器
の感度 (信号雑音比)が低いため, 光源の高強度化は重要 な課題である。本特集では，パルスおよびCW光源の高 強度化に関しての最新状況を解説頂いている. 特にパル ス光源を用いると, $\mathrm{MV} / \mathrm{cm}$ 以上のピーク電界を物質に （破壊することなく）印加可能であるため，新しい物性物 理の世界が開けつつある。また, レーザー発振には至っ ていないものの, 新しいレーザー媒質としても非常に興 味深い, グラフェンレーザーの現状と展望を解説頂いて いる。なお，量子カスケードレーザーに関しては，最近 の特集号 (2011年, 第39巻10号)があるので，そちらを参 照頂きたい.

一方，産業応用に関しても，着実に前進しており，す でにTHz波分光装置が国内外7社から市販されている. 本特集では, 最近発表されたテラヘルツ波CT装置を取 り上げた。また，市販段階ではないが，波長が(可視光 などに比べて)長いテラヘルツ波の弱点である低い空間 分解能を克服する技術として, 近接場を利用したレー ザーテラヘルツ顕微鏡，および最近活発な研究が行われ ている, テラヘルツメタマテリアルに関する最近の進展 を紹介頂いた。

テラヘルツ波技術全体では，これらの他にも様々な提 案・進展があり，いずれも興味深いが, 紙面の都合もあ り，本特集ではレーザーとの関係が深いものに限らせて 頂いた。 また本号では，オリジナル論文にも共鳴トンネ ルダイオード，およびテラヘルツ波コムに関する最新の 研究が掲載されており, 解説論文と合わせて, 最新のテ ラヘルツ波技術の進展の様子を堪能頂ければ幸いであ る. 